JAMP: Jurnal Adminitrasi dan Manajemen Pendidikan

Volume 3 Nomor 2 Juni 2020, Hal : 171-181

Tersedia Online di http://journal2.um.ac.id/index.php/jamp/

ISSN 2615-8574 (online)

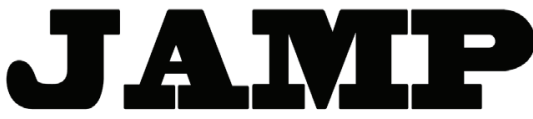

JURNAL ADMINISTRASI DAN MANAJEMEN PENDIDIKAN

\title{
PERSEPSI GURU DAN SISWA TENTANG EFEKTIVITAS MANAJEMEN KURIKULUM DAN PENGARUHNYA TERHADAP KREATIVITAS SISWA SEKOLAH MENENGAH ATAS
}

\author{
Alma'idah Hayuning Sesanti \\ Burhanuddin \\ Nurul Ulfatin \\ Jurusan Administrasi Pendidikan Fakultas Ilmu Pendidikan \\ Universitas Negeri Malang, Jl. Semarang No. 5 Malang 65145 \\ almahayuning2@gmail.com \\ burhanuddin.fip@um.ac.id \\ nurul.ulfatin.fip@um.ac.id
}

\begin{abstract}
The study aims to know teachers and students perception about curriculum management effectiveness and the effect to State High School students creativity. The study used a quantitative approach with predictive correlational design. The population in this research are 569 teachers and 3.117 11th grade students from 10 Malang's State High Schools. The samples of teacher are taken by using quota sampling and random sampling as the techniques, then the samples of student are taken by using purposive sampling. The samples in this research are 234 teachers and 312 students. Data analysis techniques those have been used are descriptive statistical analysis, normality test, linearity test, simple regression analysis, and oneway anova analysis. The results of this research show that in the entire Malang's State High School (1) curriculum management is quite effective; (2) students creativity level is high enough; (3) there is a significant influence of the curriculum management effectiveness to student creativity level; (4) there is no difference in teacher perception of curriculum management effectiveness level based on organizational factors, (5) there is no difference in student perception of self-creativity level based on individual factors, and (6) there is no difference in student perception of self-creativity level based on social factors.
\end{abstract}

Keywords: curriculum management, student creativity, teacher perception, student perception

Abstrak: Penelitian ini bertujuan untuk mengetahui persepsi guru dan siswa tentang efektivitas manajemen kurikulum dan pengaruhnya terhadap kreativitas siswa SMA. Penelitian ini menggunakan pendekatan kuantitatif dengan rancangan korelasional prediktif. Populasi dalam penelitian ini adalah 569 guru dan 3.117 siswa kelas 11 dari 10 SMA Negeri di Kota Malang. Pengambilan sampel guru dilaksanakan menggunakan teknik quota sampling dan random sampling, sedangkan pengambilan sampel siswa menggunakan teknik purposive sampling. Terdapat 234 guru dan 312 siswa yang menjadi sampel dalam penelitian ini. Teknik analisis data yang digunakan yakni teknik analisis statistik deskriptif, uji normalitas, uji linearitas, analisis regresi sederhana, serta analisis oneway anova. Hasil penelitian ini menunjukkan bahwa di seluruh SMA Negeri Kota Malang (1) manajemen kurikulum sudah cukup efektif; (2) tingkat kreativitas siswa cukup tinggi; (3) terdapat pengaruh yang signifikan dari efektivitas manajemen kurikulum terhadap tingkat kreativitas siswa; (4) tidak ada perbedaan persepsi guru terhadap tingkat efektivitas manajemen kurikulum berdasarkan faktor organisasional sekolah, (5) tidak ada perbedaan persepsi siswa terhadap tingkat kreativitas diri berdasarkan faktor individual, serta (6) tidak ada perbedaan persepsi siswa terhadap tingkat kreativitas diri berdasarkan faktor sosial.

Kata Kunci: manajemen kurikulum, kreativitas siswa, persepsi guru, persepsi siswa 
Perkembangan IPTEK yang semakin pesat membentuk spektrum luas dengan berbagai bidang kehidupan. Tugas kurikulum di tengah perkembangan IPTEK yakni menjadikan Sumber Daya Manusia (SDM) terutama yang berada di usia produktif sebagai insan yang mampu berpartisipasi aktif dalam kegiatan pembelajaran, serta memperoleh ruang untuk kehendak, kreativitas, dan kemandirian, sesuai bakat, minat, dan potensi secara fisik maupun psikologis (Peraturan Pemerintah Nomor 32 Tahun 2013 tentang Perubahan atas Peraturan Pemerintah Nomor 19 Tahun 2005 tentang Standar Nasional Pendidikan, 2013). Manajemen kurikulum yang efektif memudahkan siswa dalam mencapai tujuan pendidikan nasional, yang salah satunya yakni menjadikan siswa sebagai pribadi yang kreatif (Undang-Undang Republik Indonesia No. 20 tahun 2003 tentang Sistem Pendidikan Nasional, 2003). Kreativitas sendiri merupakan sebuah tindakan, ide, atau produk yang dapat mengubah sesuatu yang sudah ada sebelumnya menjadi suatu hal yang baru (Csikszentmihalyi, 2013). Hingga saat ini, masyarakat dan kaum intelektual masih memperdebatkan pengaruh kurikulum terhadap kreativitas siswa.

Beberapa peneliti membuktikan bahwa manajemen kurikulum yang efektif mampu meningkatkan kreativitas siswa. Seperti di tahun 2016, Diyanto melalui penelitiannya berhasil membuktikan bahwa manajemen kurikulum yang efektif mampu meningkatkan kreativitas siswa SMK Palapa Semarang sebesar 24,4\% (Diyanto, 2016). Kemudian di tahun berikutnya, Trisna, Sunandar dan Yuliejantiningsih melalui penelitiannya membuktikan bahwa Daniel Creative School yang mengutamakan peningkatan kreativitas siswa, sangat memperhatikan manajemen kurikulum di sekolah. Hal ini dikarenakan manajemen kurikulum yang efektif menjadi strategi sekolah dalam menciptakan mutu pendidikan yang baik dengan siswa yang memiliki tingkat kreativitas tinggi (Trisna et al., 2017). Namun, hasil penelitian yang demikian tidak diimbangi dengan peningkatan posisi Indonesia pada hasil pemeringkatan internasional.

Pada hasil pemeringkatan mutu pendidikan di tingkat internasional oleh Organisation for Economic Cooperation and Development (OECD) melalui Programme for International Student Assesment (PISA), menunjukkan bahwa Indonesia berada di posisi 73 dari 78 negara (OECD, 2019). Tidak hanya itu, data Global Human Capital Report yang diterbitkan oleh World Economic Forum di tahun 2017 juga menunjukkan posisi Indonesia di bidang pendidikan, yakni peringkat 65 dari 130 negara (World Economic Forum, 2017)critically, to build a future that is more inclusive and human centric. All too often however, human potential is not realized, held back either by inequality or an unrealistic and outdated faith on the part of policymakers that investment in small sub sections of highly skilled labour alone can drive sustainable, inclusive growth.","author":[\{“dropping-particle":",,"family":"World Economic Forum","given":",,"non-dropping-particle":,",,"parse-names":false,"suffix":,"”\}],"contai ner-title":"World Economic Forum","id":"ITEM-1","issued":\{“date-parts":[[“2017"]]\},"number-ofpages":"8","title":"The Global Human Capital Report 2017: Preparing for the future of work","type ":"report","volume":"0"”,"uris":[“http://www.mendeley.com/documents/?uuid=c257d5ef-1521-4f98b7c7-cd6f2dc62f79"]\}],"mendeley": \{“formattedCitation":”(World Economic Forum, 2017. Pada hasil pemeringkatan Trends in International Mathematics and Science Study (TIMSS) tahun 2015, Indonesia berada di posisi 45 dari 50 negara untuk matematika dan 45 dari 48 negara untuk sains (Provasnik et al., 2016). Perbedaan antara hasil penelitian yang dilaksanakan oleh para peneliti dengan hasil pemeringkatan internasional menjadikan masyarakat dan kaum cendekiawan masih mempersoalkan pengaruh pengelolaan kurikulum terhadap peningkatan kreativitas siswa. Sumber permasalahan tentu tidak hanya berasal dari kegiatan pengelolaan yang dilaksanakan oleh pemerintah, namun juga satuan pendidikan sebagai unit pelaksana teknis penerapan kurikulum. Upaya sekolah dalam mengelola kurikulum pun tidak hanya didukung oleh aspek internal yang melibatkan warga sekolah, namun juga aspek eksternal.

Persepsi pada dasarnya merupakan proses dimana seseorang memilih, mengorganisasikan, dan mengartikan informasi yang diperoleh untuk menciptakan suatu gambaran yang berarti (Kotler \& Keller, 2016). Terdapat beberapa hal yang menjadi ciri-ciri dari persepsi, yakni: (1) proses pengorganisasian pengalaman, (2) proses menghubungkan pengalaman masa lalu dengan pengalaman saat ini, (3) proses pemilihan informasi, (4) proses teorisasi dan rasionalisasi, (5) proses penafsiran atau pemaknaan terhadap pesan verbal dan non verbal, (6) proses interaksi dan komunikasi berbagai pengalaman internal 
dan eksternal, serta (7) proses penyimpulan yang berwujud persepsi individu (Marliani, 2014). Terdapat dua faktor yang dapat mempengaruhi perbedaan persepsi antara satu orang dengan yang lain, yakni faktor internal dan faktor eksternal. Faktor internal berasal dari dalam diri individu, sedangkan faktor eksternal berada dari luar individu yang bersangkutan (Thoha, 2014).

Manajemen kurikulum terdiri atas lima tahapan utama, yakni perencanaan, pengorganisasian, pelaksanaan, evaluasi, dan kepemimpinan. Pada tahap perencanaan kurikulum terdapat lima komponen yang perlu dibahas secara matang, yakni: (1) tujuan pembelajaran, (2) isi pelajaran, (3) aktivitas belajar, (4) sumber belajar, serta (5) evaluasi pembelajaran (Wahyudin, 2014). Kemudian dalam rangka menerapkan pengorganisasian kurikulum yang efektif, terdapat empat faktor yang harus diperhatikan oleh setiap satuan pendidikan, yaitu: (1) urutan bahan pelajaran, (2) kontinuitas, (3) keseimbangan, serta (4) keterpaduan arah kurikulum dengan ruang lingkup (Rusman, 2012). Pada tahap implementasi, terdapat tiga faktoryang mempengaruhi, yaitu: (1) karakteristik kurikulum, (2) strategi implementasi kurikulum, serta (3) karakteristik penggunaan kurikulum (Wahyudin, 2014). Selanjutnya pada tahap evaluasi kurikulum, terdapat empat prosedur yang harus dilaksanakan oleh sekolah, yakni: (1) evaluasi kebutuhan, (2) evaluasi masukan, (3) evaluasi proses, serta (4) evaluasi produk (Wahyudin, 2014). Kepala sekolah sebagai pemimpin kurikulum memiliki beberapa peranan, yakni: (1) memadukan unsur budaya setempat dengan ciri khas masing-masing mata pelajaran; (2) meningkatkan keterampilan mengajar para guru; (3) memastikan bahwa setiap guru di sekolah sudah menggunakan metode mengajar yang tepat; (4) memastikan bahwa terdapat agenda pertemuan guru secara berkala; (5) membantu guru dalam menjadikan data siswa sebagai fokus pengajaran; (6) mengembangkan manajemen tingkah laku siswa; (7) memantau data prestasi dan kehadiran siswa; (8) mengajak anggota masyarakat untuk turut mengajar di sekolah; serta (9) memiliki kepekaan terhadap ketimpangan yang disebabkan oleh gender, agama, budaya, bahasa, fisik, serta kurikulum (Wahyudin, 2014).

Lingkungan sosial siswa pada dasarnya seluruh manusia yang berada di sekitar siswa dan memiliki pengaruh terhadap siswa tersebut (Purwanto, 2017). Terdapat tiga jenis lingkungan sosial bagi siswa, yakni lingkungan keluarga, lingkungan sekolah, dan lingkungan masyarakat. Di dalam keluarga, lingkungan sosial yang dimaksud meliputi cara orang tua mendidik anak beserta suasana rumah, sedangkan di sekolah lingkungan sosial yang dimaksud meliputi relasi antar guru dan relasi antar siswa. Di dalam lingkungan masyarakat, lingkungan sosial yang dimaksud yakni bentuk kehidupan masyarakat di sekitar dan teman bergaul (Dewantara, 2010). Komponen organisasional sekolah, terdiri atas (1) tujuan organisasi, yang pada umumnya tercermin dalam visi dan misi sekolah; (2) komposisi organisasi, seperti jumlah siswa, guru, dan staf yang dimiliki; (3) prosedur kinerja organisasi, yakni dapat berwujud SOP yang membedakan setiap satuan pendidikan; serta (4) struktur sosial, yakni struktur dan prosedur kerja dari sekolah beserta sistem komunikasi di antara guru dan staf yang notabene sudah memiliki peranan masing-masing (Giacquinta, 1973).

Proses perkembangan pada manusia berdasarkan pandangan Jean Piaget terbagi atas dua periode utama, yakni periode intelegensi sensorimotor dan periode intelegensi konseptual (Hurlock, 2013). Dua periode tersebut dapat diperinci dalam empat tahapan perkembangan yang saling berhubungan satu sama lain, yakni: (1) tahap sensorimotor (0-2 tahun); (2) tahap pra operasional (2-6 tahun); (3) tahap operasi konkret (6-11 tahun); serta (4) tahap operasi formal (11 tahun hingga seterusnya). Kreativitas pada dasarnya berhubungan dengan penemuan suatu hal yang baru dengan menggunakan sesuatu yang sudah ada (Rahmawati \& Kurniati, 2010). Seorang siswa dikatakan kreatif apabila memiliki sejumlah ciri-ciri yang dapat diamati, yakni: (1) memiliki variasi ide dan sumber informasi; (2) mampu menggabungkan ide-ide yang telah dimiliki dengan hal-hal baru; (3) mampu menyadari dan menghadapi tantangan; (4) memiliki motivasi dalam menyelesaikan permasalahan (Brookhart, 2013; Fields \& Bisschoff, 2014).

Oleh karena itu, muncul sejumlah pertanyaan dalam penelitian ini, yakni apa dan bagaimana kurikulum diterapkan di sekolah. Di samping itu, faktor apakah yang diprediksi dapat mempengaruhi perkembangan kurikulum sekolah. Pertanyaan-pertanyaan tersebut untuk membuktikan ada atau tidaknya pengaruh efektivitas manajemen kurikulum terhadap tingkat kreativitas siswa, baik dari persepsi guru maupun siswa. Penelitian ini nantinya juga mencakup faktor organisasional sekolah, individual siswa, dan faktor sosial siswa sebagai aspek internal dan eskternal yang dapat mempengaruhi persepsi guru dan siswa di sekolah. 


\section{METODE}

Pada penelitian ini, peneliti menggunakan pendekatan kuantitatif dengan rancangan prediktif korelasional (Creswell, 2014). Rancangan ini diplih karena sesuai tujuannya penelitian ini mengukur sejauh mana pengaruh antar variabel. Terdapat lima variabel yang diduga memiliki pengaruh satu sama lain, yakni: (1) manajemen kurikulum $\left(\mathrm{X}_{1}\right)$; (2) organisasional sekolah $\left(\mathrm{X}_{2}\right)$; (3) individual siswa $\left(\mathrm{X}_{3}\right)$; (4) faktor sosial $\left(\mathrm{X}_{4}\right)$; serta (5) kreativitas siswa (Y). Populasi dalam penelitian ini ialah 569 guru dan 3.117 siswa kelas 11 dari 10 SMA Negeri di Kota Malang. Kemudian, peneliti menggunakan teknik quota sampling dan random sampling untuk menetukan jumlah sampel guru, serta purposive sampling untuk menetukan sampel siswa. Terdapat 234 guru dan 312 siswa yang menjadi sampel dalam penelitian ini. Instrumen pengumpulan data yang digunakan yakni angket tertutup. Terdapat beberapa teknik analisis yang digunakan peneliti dalam penelitian ini, yakni: (1) analisis statistik deskriptif, untuk menentukan kecenderungan data dari setiap variabel; (2) uji normalitas, untuk memastikan bahwa data hasil penelitian berdistribusi normal; (3) uji linearitas, untuk melihat apakah hubungan dua variabel linear; (4) analisis regresi sederhana, untuk mengetahui pengaruh dari satu variabel terhadap variabel lainnya; serta (5) analisis oneway anova, untuk mencari ada atau tidaknya perbedaan antara dua atau lebih data ordinal.

\section{HASIL}

\section{Tingkat Efektivitas Manajemen Kurikulum SMA}

Dari hasil analisis deskriptif data, diketahui bahwa manajemen kurikulum di SMA Negeri Kota Malang sudah cukup efektif pada tahap perencanaan, pelaksanaan, kepemimpinan, dan evaluasi, namun masih kurang efektif pada tahap pengorganisasian. Kondisi tersebut diketahui dari kalkulasi menggunakan formula stanfive. Kualitas pada tahap perencanaan kurikulum di sekolah, 4\% responden menyatakan sangat baik; $28 \%$ responden menyatakan baik; 36\% responden menyatakan cukup baik; $25 \%$ menyatakan kurang baik; dan 7\% responden menyatakan tidak baik. Kemudian kualitas proses pengorganisasian kurikulum, $8 \%$ responden menyatakan sangat baik; $28 \%$ responden menyatakan baik; $30 \%$ responden menyatakan cukup baik; 32\% responden menyatakan kurang baik; dan 2\% responden menyatakan tidak baik. Kualitas proses implementasi kurikulum menurut $10 \%$ responden sudah sangat baik; sedangkan $21 \%$ responden menyatakan baik; $34 \%$ responden menyatakan cukup baik; 32\% responden menyatakan kurang baik; dan 3\% responden menyatakan tidak baik. Kualitas pada proses kepemimpinan kurikulum, $11 \%$ responden menyatakan sangat baik; $18 \%$ responden menyatakan baik; $42 \%$ responden menyatakan cukup baik; 24\% responden menyatakan kurang baik; dan 5\% responden menyatakan tidak baik. Kualitas proses evaluasi kurikulum menurut $13 \%$ responden sudah sangat baik; namun 13\% responden menyatakan baik; 58\% responden menyatakan cukup baik; $11 \%$ responden menyatakan kurang baik; dan 7\% responden menyatakan tidak baik. Manajemen kurikulum di SMAN 7 Malang memiliki tingkat efektivitas paling tinggi. Di lain sisi, tingkat efektivitas manajemen kurikulum di SMAN 10 Malang terendah jika dibandingkan dengan sekolah-sekolah lainnya. Hal ini perlu mendapatkan penanganan yang tepat agar tidak berdampak negatif pada proses pembelajaran di sekolah. Berikut merupakan diagram yang menggambarkan kondisi efektivitas manajemen kurikulum di SMA Negeri Kota Malang.

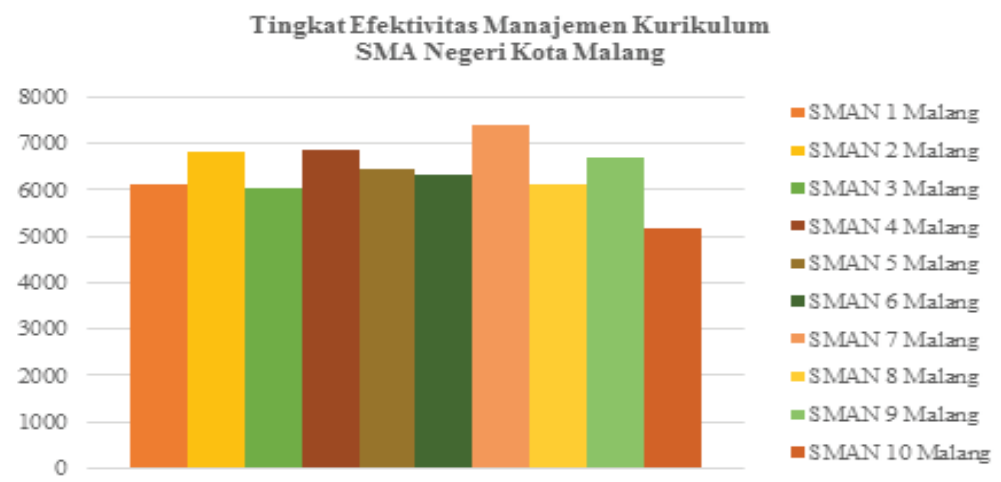

Gambar 1 Tingkat Efektivitas Manajemen Kurikulum SMA Negeri Kota Malang 


\section{Tingkat Kreativitas Siswa SMA}

Tingkat kreativitas siswa SMA Negeri di Kota Malang, baik berdasarkan persepsi guru maupun siswa sudah cukup baik pada empat indikator kreativitas. Berdasarkan persepsi guru, pada tingkat variasi ide dan sumber informasi yang dimiliki siswa, 9\% responden menyatakan sangat baik; $14 \%$ responden menyatakan baik; $53 \%$ responden menyatakan cukup baik; $13 \%$ responden menyatakan kurang baik; dan $11 \%$ responden menyatakan tidak baik. Tingkat kemampuan siswa dalam menggabungkan ide (sintesis), menurut $6 \%$ responden sudah sangat baik; namun 13\% responden menyatakan baik; $47 \%$ responden menyatakan cukup baik; 20\% responden menyatakan kurang baik; dan 5\% responden menyatakan tidak baik. Pada tingkat kemampuan siswa dalam menghadapi tantangan, 9\% responden menyatakan sangat baik; $10 \%$ responden menyatakan baik; $55 \%$ responden menyatakan cukup baik; $22 \%$ responden menyatakan kurang baik; dan 5\% menyatakan tidak baik. Kemudian tingkat motivasi siswa, menurut $9 \%$ responden sangat baik; sedangkan $8 \%$ responden menyatakan baik; $55 \%$ responden menyatakan cukup baik; $22 \%$ responden menyatakan kurang baik; dan 7\% responden menyatakan tidak baik.

Berdasarkan persepsi siswa, pada tingkat variasi ide dan sumber informasi yang dimiliki, 4\% responden menyatakan sangat baik; $27 \%$ responden menyatakan baik; $43 \%$ responden menyatakan cukup baik; $18 \%$ responden menyatakan kurang baik; dan $8 \%$ responden menyatakan tidak baik. Tingkat kemampuan dalam menggabungkan ide (sintesis), menurut $9 \%$ responden sudah sangat baik; namun $27 \%$ responden menyatakan baik; $41 \%$ responden menyatakan cukup baik; $17 \%$ responden menyatakan kurang baik; dan 5\% responden menyatakan tidak baik. Pada tingkat kemampuan dalam menghadapi tantangan, $10 \%$ responden menyatakan sangat baik; $21 \%$ responden menyatakan baik; $40 \%$ responden menyatakan cukup baik; $23 \%$ responden menyatakan kurang baik; dan $6 \%$ responden menyatakan tidak baik. Tingkat motivasi dalam menyelesaikan masalah, menurut $7 \%$ responden sudah sangat baik; sedangkan $26 \%$ responden menyatakan baik; $38 \%$ responden menyatakan cukup baik; $24 \%$ responden menyatakan kurang baik; dan 5\% responden menyatakan tidak baik. Berdasarkan persepsi para guru dan siswa SMA Negeri Kota Malang yang menjadi responden, tingkat kreativitas siswa SMAN 7 Malang paling tinggi. Di lain sisi, tingkat kreativitas siswa SMAN 10 Malang terendah jika dibandingkan dengan sekolah-sekolah lainnya. Hal ini perlu mendapatkan perhatian khusus dari pihak sekolah. Berikut diagram yang menggambarkan kondisi tingkat kreativitas siswa SMA Negeri di Kota malang, baik berdasarkan persepsi guru maupun siswa.

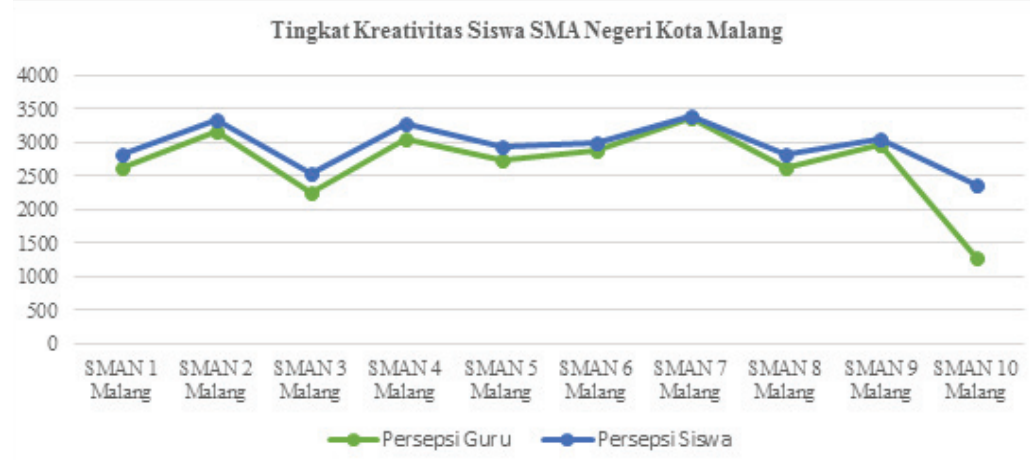

Gambar 2 Tingkat Kreativitas Siswa SMA Negeri Kota Malang Berdasarkan Persepsi Guru dan Siswa

\section{Kondisi Faktor Organisasional SMA}

Dari aspek faktor organisasional, berdasarkan hasil analisis deskriptif seluruh SMA Negeri di Kota Malang memiliki jumlah siswa yang hampir serupa, baik secara keseluruhan maupun di masingmasing tingkatan kelas yakni di atas 250 hingga di bawah 400. Jumlah guru di masing-masing sekolah berada pada kisaran 40-70 guru. Rata-rata SMA Negeri di Kota Malang sudah berdiri lebih dari 50 tahun. Dari seluruh sekolah, SMAN 10 Malang menjadi sekolah dengan usia paling muda, yakni 20 tahun. Seluruh sekolah yang dilibatkan dalam penelitian ini berakreditasi A. Hal ini ditunjukkan dengan seluruh responden menyatakan dirinya berasal dari sekolah berakreditasi A. Dari hasil analisis deskriptif menggunakan SPSS, diketahui bahwa 76 guru yang menjadi responden belum memiliki pangkat atau 
golongan; tidak ada responden yang masuk dalam golongan II; 102 responden masuk dalam golongan III; dan 56 responden masuk dalam golongan IV. Dari segi jabatan, diketahui bahwa 216 responden tidak memiliki tugas tambahan selain menjadi guru mata pelajaran dan 18 responden memiliki tugas tambahan di sekolah. Dari segi pendidikan terakhir, 168 responden menyelesaikan pendidikan hingga S1; 62 responden menyelesaikan pendidikan hingga S2; dan 4 responden menyelesaikan pendidikan hingga S3.

\section{Kondisi Individual Siswa SMA}

Dari aspek individual, siswa yang menjadi responden tidak hanya berjenis kelamin wanita, namun juga pria. Setelah dilakukan pengelolaan data menggunakan program SPSS diketahui bahwa 211 responden merupakan wanita dan 101 responden merupakan pria. Pada penelitian ini, peneliti hanya melibatkan siswa kelas 11 dari setiap SMA Negeri di Kota Malang. Dari segi usia, 1 responden berusia 14 tahun; 34 responden berusia 15 tahun; 170 responden berusia 16 tahun; 98 responden berusia 17 tahun; dan 9 responden berusia 18 tahun.

\section{Kondisi Sosial Siswa SMA}

Dari hasil analisis deskriptif menggunakan aplikasi SPSS, diketahui bahwa 23 responden merupakan anak tunggal, 119 responden memiliki 1 saudara kandung, 101 responden memiliki 2 saudara kandung, 52 responden memiliki 3 saudara kandung, 11 responden memiliki 4 saudara kandung, 2 responden memiliki 5 saudara kandung, 3 responden memiliki 6 saudara kandung, dan 1 responden memiliki 8 saudara kandung. Kemudian, diketahui bahwa ayah dari 104 responden menjalani profesi yang masuk dalam kategori "lainnya". Profesi yang dimaksud yakni profesi selain petani, pedagang, karyawan swasta, PNS, TNI, dan POLRI. Ayah 3 responden berprofesi sebagai petani, ayah 33 responden berprofesi sebagai pedagang, ayah 112 responden berprofesi sebagai karyawan swasta, dan ayah 60 responden berprofesi sebagai PNS/TNI/POLRI. Dari segi pekerjaan ibu, 206 siswa yang menjadi responden memiliki ibu yang berprofesi dalam kategori "lainnya". Profesi yang dimaksud yakni profesi selain petani, pedagang, karyawan swasta, PNS, TNI, dan POLRI. Kemudian, ibu 25 responden berprofesi sebagai pedagang, ibu 42 responden berprofesi sebagai karyawan swasta, dan ibu 39 responden berprofesi sebagai PNS/ TNI/POLRI. Jika ditinjau dari pendidikan terakhir, ayah 7 responden merupakan lulusan SD, ayah 17 responden merupakan lulusan SMP, ayah 115 responden merupakan lulusan SMA, ayah 141 responden merupakan lulusan S1, ayah 27 responden merupakan lulusan S2, dan ayah 5 responden merupakan lulusan S3. Kemudian, Ibu 2 responden tidak mengenyam pendidikan, ibu 4 responden merupakan lulusan SD, ibu 18 responden merupakan lulusan SMP, ibu 133 responden merupakan lulusan SMA, ibu 126 responden merupakan lulusan S1, ibu 18 responden merupakan lulusan S2, dan ibu 11 responden merupakan lulusan S3. Dari segi penghasilan, orang tua 81 responden 1-2 juta; orang tua 107 responden berpenghasilan 3-4 juta; orang tua 77 responden berpenghasilan 5-6 juta; dan orang tua 47 responden berpenghasilan lebih dari 6 juta.

\section{Pengaruh Tingkat Efektivitas Manajemen Kurikulum terhadap Tingkat Kreativitas Siswa SMA}

Setelah data dipastikan terdistribusi normal dan memiliki hubungan yang linier, maka peneliti melanjutkan pengelolaan data menggunakan teknik analisis regresi sederhana.

Tabel 1 Hasil Analisis Regresi Variabel Manajemen Kurikulum dan Kreativitas Siswa Berdasarkan Persepsi Guru

\begin{tabular}{ccccc}
\hline & \multicolumn{4}{c}{ Model Summary } \\
\hline Model & $\mathbf{R}$ & R Square & Adjusted R Square & $\begin{array}{l}\text { Std. Error of } \\
\text { the Estimate }\end{array}$ \\
\hline $\mathbf{1}$ & $\mathbf{0 , 2 9 2 ^ { \text { a } }}$ & $\mathbf{0 , 0 8 5}$ & $\mathbf{0 , 0 8 2}$ & $\mathbf{8 , 9 2 8}$ \\
\multicolumn{2}{l}{ a. Predictors: (Constant), Manajemen Kurikulum } &
\end{tabular}




\begin{tabular}{|c|c|c|c|c|c|c|}
\hline \multicolumn{7}{|c|}{ Coefficientsa } \\
\hline & \multirow{2}{*}{ Model } & \multicolumn{2}{|c|}{ Unstandardized Coefficients } & \multirow{2}{*}{$\begin{array}{c}\text { Standardized Coefficients } \\
\text { Beta }\end{array}$} & \multirow{2}{*}{$\mathbf{T}$} & \multirow{2}{*}{ Sig. } \\
\hline & & B & Std. Error & & & \\
\hline \multirow{2}{*}{1} & (Constant) & 51,953 & 8,995 & & 5,775 & 0,000 \\
\hline & Manajemen Kurikulum & $\mathbf{0 , 2 0 9}$ & 0,040 & 0,292 & 5,168 & $\mathbf{0 , 0 0 0}$ \\
\hline
\end{tabular}

a. Dependent Variable: Kreativitas Siswa Menurut Guru

Berdasarkan jawaban responden guru, jika tidak terdapat kenaikan skor pada efektivitas manajemen kurikulum, maka skor kreativitas siswa sebesar 51,953. Namun, penambahan satu skor efektivitas manajemen kurikulum akan memberikan kenaikan sebesar 0,209 pada skor kreativitas siswa. Jika dipersentasekan, $1 \%$ perubahan pada manajemen kurikulum sekolah akan mempengaruhi $8,5 \%$ tingkat kreativitas siswa di sekolah.

Tabel 2 Hasil Analisis Regresi Variabel Manajemen Kurikulum dan Kreativitas Siswa Berdasarkan Persepsi Siswa

\begin{tabular}{|c|c|c|c|c|c|c|c|}
\hline \multicolumn{6}{|c|}{ Model Summary } & & \\
\hline Model & $\mathbf{R}$ & R Square & \multicolumn{2}{|c|}{ Adjusted R Square } & $\begin{array}{l}\text { Std. Error of } \\
\text { the Estimate }\end{array}$ & & \\
\hline 1 & $0,119^{\mathrm{a}}$ & 0,014 & $\mathbf{0 , 0 1 1}$ & & 16,128 & & \\
\hline \multicolumn{8}{|c|}{ a. Predictors: (Constant), Manajemen Kurikulum } \\
\hline \multicolumn{8}{|c|}{ Coefficientsa } \\
\hline \multirow{2}{*}{\multicolumn{3}{|c|}{ Model }} & Unstandar & Coefficients & Standardized & \multirow{2}{*}{$\mathbf{T}$} & \multirow{2}{*}{ Sig. } \\
\hline & & & B & Std. Error & Bet & & \\
\hline \multirow{2}{*}{1} & (Constan & & 62,993 & 16,250 & & 3,876 & $\mathbf{0 , 0 0 0}$ \\
\hline & Manajem & urikulum & 0,148 & $\mathbf{0 , 0 7 3}$ & $\mathbf{0 , 1 1}$ & 2,028 & 0,043 \\
\hline
\end{tabular}

a. Dependent Variable: Kreativitas Siswa

Berdasarkan jawaban responden siswa, jika tidak terdapat kenaikan skor dari efektivitas manajemen kurikulum, maka skor kreativitas siswa sebesar 62,993. Kemudian, penambahan satu skor efektivitas manajemen kurikulum $\left(\mathrm{X}_{1}\right)$ akan memberikan kenaikan sebesar 0,148 pada skor kreativitas siswa. Jika dipersentasekan, perubahan $1 \%$ pada manajemen kurikulum sekolah akan mempengaruhi 1,4\% tingkat kreativitas siswa di sekolah. Dari hasil analisis regresi sederhana ini dapat disimpulkan bahwa efektivitas manajemen kurikulum memiliki pengaruh yang signifikan pada kreativitas siswa, baik dari persepsi guru maupun siswa.

\section{Persepsi Guru terhadap Tingkat Efektivitas Manajemen Kurikulum Ditinjau dari Faktor Organisasional Sekolah}

Sebelum dilanjutkan pada analisis oneway anova, data telah dipastikan bersifat homogen setelah melalui Test of Homogenity of Variances. Pada hasil analisis oneway anova, nilai signifikansi yang diperoleh masing-masing aspek yakni 0,$911 ; 0,639$; dan $0,133(>0,01)$. Oleh karena itu, dapat disimpulkan bahwa tidak ada perbedaan persepsi pada guru yang menjadi responden terhadap tingkat efektivitas manajemen kurikulum di sekolah, meskipun memiliki perbedaan faktor organisasional yang meliputi aspek golongan, jabatan, dan pendidikan terakhir.

\section{Persepsi Siswa terhadap Tingkat Kreativitas Diri Ditinjau dari Faktor Individual}

Setelah data dipastikan bersifat homogen melalui Test of Homogenity of Variances, peneliti melanjutkan analisis statistik menggunakan teknik oneway anova. Pada hasil analisis oneway anova, nilai signifikansi yang diperoleh masing-masing aspek yakni 0,865 dan $0,460(>0,01)$. Oleh karena itu, dapat disimpulkan bahwa tidak ada perbedaan persepsi pada siswa yang menjadi responden terhadap tingkat kreativitas dirinya, meskipun memiliki perbedaan faktor individual yang meliputi aspek jenis kelamin dan usia. 


\section{Persepsi Siswa terhadap Tingkat Kreativitas Diri Ditinjau dari Faktor Sosial}

Peneliti melaksanakan analisis statistik menggunakan teknik oneway anova, setelah data dipastikan bersifat homogen melalui Test of Homogenity of Variances Pada hasil analisis oneway anova, nilai signifikansi yang diperoleh masing-masing aspek yakni 0,$641 ; 0,150 ; 0,243 ; 0,126 ; 0,266 ;$ dan 0,267 $(>0,01)$. Oleh karena itu, dapat disimpulkan bahwa tidak ada perbedaan persepsi pada siswa yang menjadi responden terhadap tingkat kreativitas dirinya, meskipun memiliki perbedaan faktor sosial yang meliputi aspek jumlah saudara kandung, pekerjaan ayah dan ibu kandung, pendidikan terakhir ayah dan ibu kandung; serta penghasilan orang tua.

\section{PEMBAHASAN}

\section{Tingkat Efektivitas Manajemen Kurikulum SMA}

Berdasarkan hasil penelitian, diketahui bahwa proses manajemen kurikulum di seluruh SMA Negeri Kota Malang berjalan cukup efektif, pada tahap perencanaan, implementasi, kepemimpinan, dan evaluasi kurikulum. Namun, tahap pengorganisasian kurikulum masih belum dilaksanakan secara efektif. Dari 10 sekolah yang diteliti, diketahui bahwa manajemen kurikulum di SMAN 7 Malang memiliki tingkat efektivitas paling tinggi. Namun, di lain sisi tingkat efektivitas manajemen kurikulum SMAN 10 Malang berada di posisi paling akhir. Perbedaan pencapaian tingkat efektivitas manajemen kurikulum pada masing-masing sekolah didasari kondisi organisasional sekolah yang berbeda-beda, yakni pada komposisi organisasi, SMAN 7 Malang berdasarkan hasil analisis deskriptif, diketahui memiliki jumlah guru yang lebih banyak jika dibandingkan dengan satuan pendidikan lainnya yakni sejumlah 65 guru, disusul dengan SMAN 2 Malang dan SMAN 9 Malang. Demikian berbeda dengan SMAN 10 Malang yang memiliki jumlah guru yang lebih sedikit dibandingkan dengan sekolah lainnya, yakni sejumlah 47 guru. Jumlah guru juga sangat menentukan pembentukan struktur sosial di sekolah dan bagaimana manajemen kurikulum di sekolah mampu mencapai tingkat efektivitas yang tinggi (Giacquinta, 1973). Proses pengorganisasian kurikulum yang tergolong belum efektif harus segera diatasi, karena berdasarkan studi literatur yang dilaksanakan oleh Sugiana di tahun 2018, diketahui bahwa pengorganisasian kurikulum memegang peranan krusial dalam menentukan urutan bahan pelajaran yang dibutuhkan untuk mencapai tujuan pendidikan secara efektif dan efisien (Sugiana, 2018). Pengorganisasian kurikulum yang belum efektif harus dibenahi baik secara vertikal dengan meliputi peranan setiap personil yang berada dalam struktur organisasi, maupun secara horizontal dengan memperhatikan urutan program maupun bahan belajar yang akan diberikan pada siswa (Malekian \& Aliabadi, 2012).

\section{Tingkat Kreativitas Siswa SMA}

Dari hasil analisis deskriptif, diketahui bahwa tingkat kreativitas siswa SMA Negeri di Kota Malang cukup baik dalam seluruh indikator. Siswa SMAN 7 Malang memiliki tingkat kreativitas paling baik jika dibandingkan dengan satuan pendidikan lainnya. Namun, di lain sisi tingkat kreativitas siswa SMAN 10 Malang berada di posisi paling akhir. Hal ini dikarenakan manajemen kurikulum yang pada dasarnya memberi pengaruh yang signifikan pada tingkat kreativitas siswa dipengaruhi oleh faktor organisasional sekolah. Perbedaan faktor organisasional tersebut menjadikan sekolah memiliki kemampuan yang berbeda-beda dalam menjadikan manajemen kurikulum di sekolah memiliki tingkat efektivitas yang tinggi (Giacquinta, 1973). Pencapaian ini harus senantiasa ditingkatkan melalui berbagai upaya. Salah satu cara yang dapat diterapkan untuk meningkatkan kreativitas siswa yakni dengan menyelenggarakan proses pembelajaran di luar kelas dan memberikan beberapa proyek tugas yang melibatkan kontribusi siswa secara dominan (Astuti, 2015).

\section{Pengaruh Efektivitas Manajemen Kurikulum terhadap Tingkat Kreativitas Siswa}

Berdasarkan hasil analisis regresi sederhana, diketahui bahwa efektivitas manajemen kurikulum di sekolah berpengaruh pada tingkat kreativita siswa, baik berdasarkan persepsi guru, maupun siswa. Jika terdapat peningkatan efektivitas manajemen kurikulum, maka akan terjadi peningkatan kreativitas belajar siswa. Hasil penelitian tersebut menginterpretasikan peranan kurikulum sebagai komponen pendidikan 
yang strategis, yang salah satunya yakni: peranan kreatif dengan menciptakan suatu hal yang baru dan sesuai dengan kebutuhan masyarakat di masa kini dan masa mendatang (Hamalik, 2013). Kurikulum yang diterapkan di Indonesia saat ini adalah Kurikulum 2013 yang meletakkan kontribusi siswa pada posisi dominan, sehingga siswa dapat lebih leluasa meningkatkan kreativitasnya (Peraturan Pemerintah Nomor 32 Tahun 2013 tentang Perubahan atas Peraturan Pemerintah Nomor 19 Tahun 2005 tentang Standar Nasional Pendidikan, 2013). Terdapat beberapa faktor yang dapat mempengaruhi perkembangan kreativitas siswa, salah satunya yakni sekolah (Wiyani, 2014). Oleh karena itu, sekolah harus mampu mengelola kurikulumnya secara efektif agar berpengaruh positif pada peningkatan kreativitas siswa.

\section{Persepsi Guru terhadap Tingkat Efektivitas Manajemen Kurikulum Ditinjau dari Faktor Organisasional Sekolah}

Pada hasil analisis oneway anova, diketahui bahwa guru yang menjadi responden tidak memiliki perbedaan persepsi terhadap tingkat efektivitas manajemen kurikulum di sekolah meskipun memiliki kondisi organisasional yang berbeda-beda. Pada aspek pangkat atau golongan guru, hasil penelitian ini selaras dengan hasil penelitian Adii di tahun 2017, yang menyatakan bahwa perbedaan golongan pada guru tidak menjadikan persepsi guru berbeda-beda terhadap suatu hal (Adii, 2017). Hal ini dikarenakan golongan hanya ukuran atas pengetahuan dan keterampilan yang dimiliki guru (Kementerian Pendidikan dan Kebudayaan, 2019). Golongan bukan faktor internal yang mampu mempengaruhi persepsi guru terhadap tingkat efektivitas manajemen kurikulum di sekolah (Thoha, 2014). Aspek jabatan juga tidak menjadikan guru memiliki perbedaan persepsi. Hal ini dikarenakan pemberian jabatan atau tugas tambahan pada guru bertujuan untuk pemenuhan beban kerja dalam melaksanakan pembelajaran, bukan sebagai ukuran atas persepsi yang dimiliki terhadap hal-hal yang terjadi di sekolah (Peraturan Menteri Pendidikan dan Kebudayaan Republik Indonesia Nomor 15 Tahun 2018 tentang Pemenuhan Beban Kerja Guru, Kepala Sekolah, dan Pengawas Sekolah, 2018). Pada aspek pendidikan terakhir guru, hasil penelitian ini selaras dengan hasil penelitian Nuraheni di tahun 2011 yang menyatakan bahwa perbedaan tingkat pendidikan tidak menjadikan guru memiliki perbedaan persepsi terhadap hal-hal tertentu (Nuraheni, 2011). Pendidikan terakhir merupakan ukuran kualifikasi guru sebagai pengajar, bukan ukuran atas tingkat persepsi guru di sekolah saat menilai suatu objek (Peraturan Pemerintah Republik Indonesia Nomor 19 Tahun 2017 tentang Perubahan Atas Peraturan Pemerintah Nomor 74 Tahun 2008 tentang Guru, 2017).

\section{Persepsi Siswa terhadap Tingkat Kreativitas Diri Ditinjau dari Faktor Individual}

Dari hasil analisis statistik menggunakan teknik oneway anova, diketahui bahwa siswa yang menjadi responden tidak memiliki perbedaan persepsi terhadap tingkat kreativitas dirinya meskipun memiliki perbadaan kondisi idividual. Pada aspek jenis kelamin, hasil penelitian ini selaras dengan hasil penelitian Hamama, Hallaby, dan Ramona di tahun 2019 yang menyatakan bahwa tidak ada perbedaan persepsi pada siswa, meskipun memiliki perbedaan jenis kelamin (Hamama et al., 2019). Jenis kelamin sendiri benar merupakan konsep yang digunakan untuk mengidentifikasi perbedaan laki-laki dan wanita dari segi sosial, budaya, dan psikologis (Arbain et al., 2017). Namun, pembentukan persepsi pada seseorang tidak hanya dipengaruhi oleh kepribadian secara internal melainkan juga hubungan individu dengan objek yang dinilainya secara eksternal (Marliani, 2014). Begitu juga dengan usia, yang meskipun menjadi ukuran tahap perkembangan siswa namun tidak menjadi faktor tunggal dalam pembentukan persepsi.

\section{Persepsi Siswa terhadap Tingkat Kreativitas Diri Ditinjau dari Faktor Sosial}

Pada hasil analisis oneway anova, diketahui bahwa meskipun memiliki perbedaan faktor sosial yang meliputi aspek jumlah saudara, pekerjaan ayah dan ibu kandung, pendidikan terakhir ayah dan ibu kandung, serta penghasilan orang tua, namun demikian tidak menjadikan siswa berbeda persepsi tentang tingkat kreativitas dirinya. Seluruh aspek tersebut benar merupakan aspek yang hadir dari keluarga sebagai salah satu lingkungan sosial siswa yang dapat mempengaruhi perkembangan kreativitas pada siswa (Wiyani, 2014). Namun, proses pembentukan persepsi tidak hanya dipengaruhi faktor sosial siswa sebagai faktor eksternal, melainkan juga ada pengaruh dari faktor internal (Marliani, 2014). 


\section{KESIMPULAN DAN SARAN}

\section{Kesimpulan}

Berdasarkan hasil penelitian dapat disimpulkan bahwa: (1) manajemen kurikulum di SMA Negeri Kota Malang sudah cukup efektif pada tahap perencanaan, implementasi, kepemimpinan, dan evaluasi kurikulum, namun belum efektif pada tahap pengorganisasian; (2) berdasarkan persepsi guru dan siswa yang menjadi responden, tingkat kreativitas siswa SMA Negeri Kota Malang sudah cukup baik dalam keempat aspek, yakni variasi ide dan informasi, kemampuan sintesis ide, kemampuan menghadapi tantangan, serta motivasi dalam menyelesaikan permasalahan; (3) berdasarkan persepsi guru dan siswa yang menjadi responden, terdapat pengaruh yang signifikan dari tingkat efektivitas manajemen kurikulum terhadap tingkat kreativitas siswa; (4) tidak ada perbedaan persepsi guru terhadap tingkat efektivitas manajemen kurikulum, ditinjau dari faktor organisasional sekolah yang meliputi pangkat, jabatan, dan pendidikan terakhir guru; (5) tidak ada perbedaan persepsi siswa terhadap tingkat kreativitas diri, ditinjau dari faktor individual yang meliputi jenis kelamin dan usia siswa; serta (6) tidak ada perbedaan persepsi siswa terhadap tingkat kreativitas diri, ditinjau dari faktor sosial yang meliputi jumlah saudara, jenis pekerjaan ayah dan ibu kandung, pendidikan terakhir ayah dan ibu kandung, serta pendapatan orang tua.

\section{Saran}

Saran yang dikemukakan dalam penelitian ini yaitu: (1) Kepala sekolah harus senantiasa memantau dan ikut andil pada pemilihan pihak-pihak yang bekerja di bidang kurikulum beserta pembagian tugasnya untuk memperbaiki tahapan pengorganisasian kurikulum yang belum efektif; (2) Wakil Kepala Sekolah bagian Kurikulum harus memastikan kembali apakah pembagian tugas terhadap personilpersonil di bidang kurikulum sudah tepat dan program-program kurikulum sudah terorganisir dengan baik; (3) Guru sebaiknya lebih berinovasi dalam menyajikan materi belajar pada siswa; (4) Siswa sebaiknya menjadikan hasil penelitian sebagai masukan utuk mengetahui kondisi tingkat kreativitasnya dan memahami pentingnya meningkatkan kemampuan dalam keempat aspek kreativitas; serta (5) Peneliti lainnya dapat menggunakan model penelitian ini untuk mengukur pengaruh tingkat efektivitas manajemen kurikulum terhadap tingkat kreativitas siswa, namun untuk pengukuran variabel faktor organisasional sekolah, individual siswa, dan faktor sosial siswa dapat digunakan teknik pengumpulan data lainnya yang mampu menghasilkan data interval agar dapat lebih diketahui pengaruh antar variabel tersebut.

\section{DAFTAR RUJUKAN}

Adii, T. A. (2017). Persepsi Guru terhadap Supervisi Akademik Ditinjau dari Lama Mengajar dan Pangkat atau Golongan: Survei pada Guru SD dan SMP Negeri Terakreditasi A di Kecamatan Kalasan.

Arbain, J., Azizah, N., \& Sari, I. N. (2017). Pemikiran Gender Menurut Para Ahli: Telaah atas Pemikiran Amina Wadud Muhsin, Asghar Ali Engineer, dan Mansour Fakih. Sawwa: Jurnal Studi Gender, 11(1), 75. https:// doi.org/10.21580/sa.v11i1.1447

Astuti, R. (2015). Meningkatkan Kreativitas Siswa dalam Pengolahan Limbah Menjadi Trash Fashion Melalui PjBL. Bioedukasi: Jurnal Pendidikan Biologi, 8(2), 37. https://doi.org/10.20961/bioedukasi-uns.v8i2.3872

Brookhart, S. M. (2013). Assessing Creativity. Creativity Now!, 70(5), 28-34. http://www.ascd.org/publications/ educational-leadership/feb13/vol70/num05/Assessing-Creativity.aspx

Creswell, J. W. (2014). Research Design: Qualitative, Quantitative, and Mixed Methods Approaches. SAGE Publications. http://fe.unj.ac.id/wp-content/uploads/2019/08/Research-Design_Qualitative-Quantitativeand-Mixed-Methods-Approaches.pdf

Csikszentmihalyi, M. (2013). Creativity: Flow and The Psychology of Discovery and Invention. Harper Perennial. Dewantara. (2010). Membangun Kepribadian dan Watak Bangsa Indonesia. Pustaka Belajar.

Diyanto, E. W. (2016). Pengaruh Manajemen Kurikulum dan Kinerja Guru terhadap Hasil Belajar Siswa SMK Palapa Semarang [Universitas Negeri Semarang]. ib.unnes.ac.id/27497/1/5201409033.pdf

Fields, Z., \& Bisschoff, C. A. (2014). Developing and Assessing a Tool to Measure the Creativity of University Students. Journal of Social Sciences, 38(1), 23-31. https://doi.org/10.1080/09718923.2014.11893233 
Giacquinta, J. B. (1973). 6: The Process of Organizational Change in Schools. Review of Research in Education, 1(1), 178-208. https://doi.org/10.3102/0091732X001001178

Hamalik, O. (2013). Dasar-Dasar Pengembangan Kurikulum. Remaja Rosdakarya.

Hamama, S. F., Hallaby, S. F., \& Ramona, S. (2019). Analisis Persepsi Siswa Berdasarkan Gender terhadap Pembelajaran Biologi di Dalam Kelas. Jurnal Dedikasi Pendidikan, 8848(1), 21-26. http://jurnal.abulyatama. ac.id/index.php/dedikasi/article/download/113/113

Hurlock, E. B. (2013). Perkembangan Anak (M. Tjandrasa (ed.)). Erlangga.

Undang-Undang Republik Indonesia Nomor 20 tahun 2003 tentang Sistem Pendidikan Nasional, (2003). https:// kelembagaan.ristekdikti.go.id/wp-content/uploads/2016/08/UU_no_20_th_2003.pdf

Peraturan Pemerintah Republik Indonesia Nomor 19 Tahun 2017 tentang Perubahan Atas Peraturan Pemerintah Nomor 74 Tahun 2008 tentang Guru, (2017). https://jdih.kemdikbud.go.id/arsip/PP_Tahun2017_Nomor019. pdf

Peraturan Pemerintah Nomor 32 Tahun 2013 tentang Perubahan atas Peraturan Pemerintah Nomor 19 Tahun 2005 tentang Standar Nasional Pendidikan, (2013). https://kelembagaan.ristekdikti.go.id/wp-content/ uploads/2016/08/PP0322013.pdf

Peraturan Menteri Pendidikan dan Kebudayaan Republik Indonesia Nomor 15 Tahun 2018 tentang Pemenuhan Beban Kerja Guru, Kepala Sekolah, dan Pengawas Sekolah, (2018). http://simpuh.kemenag.go.id/regulasi/ permendikbud_15_18.pdf

Kementerian Pendidikan dan Kebudayaan. (2019). Jabatan Fungsional Guru untuk Penghargaan Karir. Kementerian Pendidikan dan Kebudayaan. https://www.kemdikbud.go.id/main/blog/2019/08/jabatanfungsional-guru-untuk-penghargaan-karir-guru

Kotler, P., \& Keller, K. (2016). Marketing Management. Pearson Education Inc.

Malekian, F., \& Aliabadi, F. M. (2012). Review of Methods of Organizing the Content of the Curriculum in the Educational System, based on ICT (Information and Communication Technology) from the Experts' View. Procedia - Social and Behavioral Sciences, 51(1), 19-23. https://doi.org/10.1016/j.sbspro.2012.08.112

Marliani, R. (2014). Psikologi Umum. CV Pustaka Setia.

Nuraheni, R. H. (2011). Persepsi Guru SMA terhadap Program Pendidikan Profesi Guru yang Terbuka Bagi Sarjana Non-Kependidikan Ditinjau dari Status Kepegawaian, Tingkat Pendidikan, dan Masa [Universitas Sanata Dharma Yogyakarta]. https://repository.usd.ac.id/10546/2/061334061_Full.pdf

OECD. (2019). PISA 2018 Results: Combined Executive Summaries. In Journal of Chemical Information and Modeling (Vol. 53, Issue 9). https://doi.org/10.1017/CBO9781107415324.004

Provasnik, S., Malley, L., Stephens, M., Landeros, K., Perkins, R., \& Tang, J. H. (2016). Highlights From TIMSS And TIMSS Advanced 2015: Mathematics And Science Achievement Of U.S. Students In Grades 4 And 8 And In Advanced Courses At The End Of High School In An International Context. (NCES 2017-002). In National Center for Education Statistics. http://nces.ed.gov/pubsearch

Purwanto, M. N. (2017). Psikologi Pendidikan. Remaja Rosdakarya.

Rahmawati, Y., \& Kurniati, E. (2010). Strategi Pengembangan Kreativitas Pada Anak Usia Taman Kanak-Kanak. Kencana.

Rusman. (2012). Manajemen Kurikulum. Rajawali Pers.

Sugiana, A. (2018). Proses Pengembangan Organisasi Kurikulum dalam Meningkatkan Pendidikan di Indonesia. Pedagogik, 05(02), 257-273. https://ejournal.unuja.ac.id/index.php/pedagogik

Thoha, M. (2014). Perilaku Organisasi: Konsep Dasar dan Aplikasinya. Rajawali Pers.

Trisna, F. D., Sunandar, \& Yuliejantiningsih, Y. (2017). Manajemen Kurikulum pada Daniel Creative School Semarang. 75-88. https://www.researchgate.net/publication/322085503_Manajemen_Kurikulum_Pada_ Daniel_Creative_School_Semarang.

Wahyudin, D. (2014). Manajemen Kurikulum. Remaja Rosdakarya.

Wiyani, N. A. (2014). Psikologi Perkembangan Anak Usia Dini. Gava Media.

World Economic Forum. (2017). The Global Human Capital Report 2017: Preparing for the future of work. In World Economic Forum (Vol. 0). https://doi.org/ISBN 978-1-944835-10-1. 